
\title{
25 Research Square \\ Effects of Parental Education and Wealth on Early Childhood Stunting in Bangladesh
}

Tuhinur Rahman Chowdhury ( $\nabla$ tuhinchy.sust@gmail.com )

North Dakota State University https://orcid.org/0000-0002-9099-1279

\section{Sayan Chakrabarty}

University of Southern Queensland

\section{Muntaha Rakib}

Shahjalal University of Science \& Technology, Sylhet

\section{Stephen Winn}

University of Southern Queensland

Jason Bennie

University of Southern Queensland

\section{Research}

Keywords: Child Stunting, Parental education, Wealth index, Child undernutrition, Bangladesh

Posted Date: November 17th, 2021

DOI: https://doi.org/10.21203/rs.3.rs-1048134/v1

License: (9) (1) This work is licensed under a Creative Commons Attribution 4.0 International License. Read Full License 


\section{Abstract \\ Background}

Malnutrition is considered to be a major public health challenge, which is associated with a range of health issues, including childhood stunting. Stunting is a reliable and well-recognized indicator of chronic childhood malnutrition. The objective of this study is to determine the effects of parental education and wealth on different specification of stunting among 17490 children below five years of age in Bangladesh.

\section{Methods}

Correlates of child stunting were examined using data generated by a cross-sectional cluster survey conducted in Bangladesh in 2019. The data includes a total of 17490 children (aged < 5 years) from 64400 households. Multiple logistic regressions were used to determine the risk factors associated with child stunting and severe stunting.

\section{Results}

The prevalence of stunting and severe stunting for children was $25.96 \%$ and $7.97 \%$, respectively. Children aged 24 to $<36$ months [Odds Ratio $(\mathrm{OR})=2.65,95 \% \mathrm{Cl}: 2.30,3.05$ ] and aged 36 to $<48$ months [OR $=2.33,95 \% \mathrm{Cl}$ : $2.02,2.69]$ had more risk of stunting compared to the children aged $<6$ months. Children from Sylhet division had the greatest risk of stunting of all the eight divisions [OR $=1.26,95 \% \mathrm{Cl}: 1.09,1.46]$. Children of secondary complete or higher educated mothers were less likely to develop stunting [OR $=0.66,95 \% \mathrm{Cl}: 0.56,0.79]$ compared with children of mothers having no education at all. Similarly, children of secondary complete or higher educated father [OR $=0.74,95 \% \mathrm{Cl}: 0.63,0.87]$ were found to have lower risk of stunting compared with children whose father hadn't any education. Substantially lower risk of stunting was observed among children whose mother and father both completed secondary education or above [OR $=0.59,95 \% \mathrm{Cl}: 0.52,0.69]$. Children from richest households [OR $=0.49,95 \% \mathrm{Cl}: 0.41,0.58$ ] had $51 \%$ smaller odds on stunting compared to children from poorest families.

\section{Conclusions}

After controlling for socioeconomic and demographic factors, parental education and household position in wealth index were found as to be the most important determinants of child stunting in Bangladesh.

\section{Background}

Malnutrition represents an insufficient intake of calories and nutrients that results in illness and in extreme cases, death [1]. Malnutrition among children poses serious health threat to survival and it is linked to 3.1 million child deaths globally

[8]. Among developing countries, it is estimated 13 million children who are below five years of age die annually, of which malnutrition is among the leading cause $[2,6]$. 
Malnutrition is an impediment in the successful achievement of Sustainable Development Goals (SDGs) as it reduces the productivity of an individual and consequently negatively effecting the likelihood of future economic growth. As one of the top performing countries in Millennium Development Goals (MDGs), Bangladesh is particularly keen to embrace the new SDGs targets. For example, reducing the proportion of stunting among children under-five years of age from $36.1-25 \%$ is integrated to the 7th Five Year Plan of Bangladesh Government (2016-2020) to achieve the national SDG targets.

Height-for-age is one of the prominent parameters to investigate malnutrition status of a child [3]. According to the World Health Organisation (WHO), a child is regarded as stunted when his/her height <-2 standard deviations from child growth standard median for the same age and the same sex [4]. Stunting represents linear growth delay by a child. Globally, 159 million children are classified as stunted, indicating the prevalence rate of $23.8 \%$ [5]. Other negative health consequences of stunting among children include, a reduce recovery capacity from disease [10] increased risk of future adult obesity [11], poor cognitive functioning such as loss of memory, lower achievement in learning and increased attention deficit [12]. Stunting is estimated to be responsible for 1.2 million child deaths globally under five years old [8]. Malaria and pneumonia are more prevalent among children who are stunted and there are strong evidences for that $[7,9]$. It is associated with unfavourable pregnancy outcome [14]. Stunting has worked and continues as a hindrance to the human capital development because of its negative impact on economic productivity of adults [65].

Recently, public health researchers have examined the factors associated with the risk of stunting. Most studies have shown that socioeconomic and demographic factors are key correlates of child stunting [17]. Among a sample of Nigerian children, low maternal education is associated two-fold increase for the risk of child stunning. [18]. Socioeconomic status is another factor associated with child stunting. Children from a higher socioeconomic status have significant lower risk of stunting, compared to children from a low socioeconomic status [2]. Ricci [20] found that among Philippine children, a combination of factors, such as high socioeconomic status, being female, breastfeeding and more frequent prenatal care are important for reducing the risk of child stunting.

While these studies offer some insight into the factors associated with stunting across different countries, to date, little is known about how parental education and socio-economic status influence stunting among children five years old and below in Bangladesh. However, data suggest that Bangladesh is among the highest child stunting prevalent countries of the world, with stunting prevalence rate of $36.1 \%$, which ranks it 107 out of 132 countries when the countries are ranked from lowest to highest for the prevalence of stunting [5]. Therefore, identifying the factors associated with child stunting in Bangladesh is a public health priority. In addition to stunting, severe stunting which is defined as height <-3 standard deviations from child growth standard median for the same age and the same sex [4] is also in our interest since it is a measure of severely growth impairment for a child. Understanding risk factors for both stunting and sever stunting would help policy formulation in order to combat child chronic undernutrition problem. The aim of this study is to explore the effect of parental education and wealth on the risk of stunting and severe stunting among a large sample of children five years and below in Bangladesh.

\section{Data And Method}


Data were drawn from Multiple Indicators Cluster Survey (MICS) 2018-19[21]. This survey was carried out by the Bangladesh Bureau of Statistics with the support of the United Nations International Children's Emergency Fund (UNICEF). The survey was conducted from January 19 to June 1, 2019 with the purpose of collecting data on important indicators at the national level for the eight divisions of the country. The survey sample was selected using a two-stage stratified cluster sampling approach, using the 2011 census frame to select clusters. Standardised questionnaires were used in all data collection. More details on study design, sampling procedure, data collection, data processing and data entry can be found in "Bangladesh Multiple Indicator Cluster Survey 2019, Progotir Pathey: Final Report" [21]. The data include complete information on 64,400 households and the questionnaires were completed by parents of 23099 children, five years of age and younger. Children with no information about height-for-age-z scores were excluded from this analysis. Households with more than one child under five years of age, only the youngest one was selected for our study. Our final sample is composed of 17490 children below five years of age.

\section{Statistical analysis}

Nutritional status of a child is examined using three anthropometric measures: height-for-age $z$ scores, weightfor-age z scores and weight-for-height z scores [50]. We used the Multiple Indicator Cluster Survey 2019 (MICS) provided for height-for-age $z$ scores for generating dependent variable (stunting condition), as long-term growth of children can be reflected by height-for-age z scores and it also can capture the effects of chronic malnutrition. Using WHO child growth standards as reference [51], the prevalence of childhood stunting in our sample was assessed using two classifications: (i) 'stunted': defined as height-for-age z-scores less than -2 standard deviations; and (ii) 'severely stunted': defined as children with height-for-age z-scores less than -3 standard deviations.

We developed two separate models; (i) one to examine the associations of parental education and wealth with child stunting status [table 2] and (ii) with child severe stunting status given other factors [table 4]. For the first model, the dependent variable was dichotomous ('stunted' vs. 'not stunted'). For the second model, our dependent variable was also dichotomous ('severely stunted' vs 'not severely stunted') [61].

Independent variables included in the model are household member, age, gender, area, education of mother, education of father, wealth index quintile [40,62], type of toilet facility [20], number of under five children in a household [62] salt iodization test outcome [55] and division [2]. To determine if there was any association between child stunting and the size of household, the household size was categorized in three categories based on the number of household member in each household (up to three members, four to six members and seven or more). This was included because family size is an important determinant of child malnutrition as is caring for children and availability of food for consumption dependant on the number household members [48, 49].

Children's ages were divided into six categories ( 0 to $<6,6$ to $<12,12$ to $<24,24$ to $<36,36$ to $<48$ and 48 to $<60$ ) with children less than six months $(0$ to $<6)$ as reference category. Children's age was included in the model as it has been reported by many studies as a significant predictor of child stunting status [40,52].

We included gender as an independent variable to examine if there was any significant difference of likelihood on stunting between male and female children. Administrative geography of Bangladesh is divided into 8 divisions and we included division as a predictor variable in the regression model. Data were collected from all the eight divisions in Bangladesh; Dhaka, Barisal, Chittagong, Khulna, Rajshahi, Rangpur, Sylhet and 
Mymensingh. Several studies on child under-nutrition in Bangladesh used geographical location (division) as a predictor of child stunting $[2,53]$. Area (Urban/rural) variable was also included in the model. It is the most common variable included in almost all studies conducted in Bangladesh for identifying socioeconomic risk factors of malnourished children in Bangladesh [2, 33, 40, 53].

We included education of the mother and education of the father in our regression model to examine their role on the risk of child stunting and severe stunting. Parental education, both for education level of father and that of mother, was categorized into four categories based on the number of years of schooling; none for no schooling, primary schooling (years 1 to $<6$ ), secondary incomplete (years 6 to $<10$ ) and secondary complete or higher $(\geq 10)$.

Wealth index was used as the indicator of socioeconomic status of households. Wealth index was constructed by principal components analysis in Bangladesh Multiple Indicators Cluster Survey 2019. In calculating wealth index, source of water, type of housing, type of toilet facility, type of fuels for cooking, electricity, bank account, some durable goods and animals were taken into consideration [21]. Households were assigned wealth score depending on the asset they owned. We used wealth scores of our sampled households to rank them and the households were then divided into five equal portions (quintiles) from poorest to wealthiest, such as poorest, second, middle, fourth and wealthiest. To assess the impact of latrine facilities on child stunting and severe stunting, we included type of toilet facility as predictor variable in our model. lodine is essential micronutrient and sufficient intake of iodine is necessary for normal growth [54]. Farebrother et.al. [54] also argued that sufficient intake of iodine prevents stunted growth and if the required daily minimum intake of iodine is not met, growth will be hampered. We therefore included salt iodization test outcome in our regression model to accommodate the role of iodized salt in reducing the risk of stunting among children who were five years and below age. In multiple indicators cluster survey 2019, salt iodization test was carried out in each household and the result was classified into four categories namely, 0 PPM (not iodized), more than 0 PPM and less than 15 PPM, 15 PPM or more and no salt in the household. 15 PPM means salt containing 15 parts per million (PPM) of iodate or iodide. In this survey, a cut-off point was set at $15 \mathrm{ppm}$ indicating that salt containing $15 \mathrm{ppm}$ or more of iodate or iodide will be considered as adequately iodized [21].

As our dependent variable in the first model was binary in nature ('stunted' vs 'not stunted'), we used binary logistic regression model to determine the relationship between socio-demographic factors and child stunting. Likewise, dependent variable in the second model was dichotomous ('severely stunted' vs not 'severely stunted'). Therefore, we also used a binary logistic regression model to determine the association between sociodemographic factors and child severe stunting. We found no evidence for multicollinearity using a test for variance inflation factor (VIF) with estimated mean VIF of 1.72, implies that level of multicollinearity is within tolerance limit [63].

\section{Results}

\section{Descriptive characteristics of the sample}

Table 1 shows the socioeconomic and background characteristics of the sample and the bivariate distribution of stunting and severe stunting with sample characteristics. Data were available for 17490 children aged $<5$ years. A total $25.96 \%$ children were estimated to be stunted, and $7.97 \%$ severely stunted. More than half of the children 
were male $(52.53 \%)$. Children from Dhaka division comprised the highest proportion (18.93\%) and the lowest percentage of study children were from Mymensingh division (6.11\%). Most of the children (68.64\%) were living in households with 4-6 family members. Approximately one quarter of mothers had not gone to school, however the highest proportion of mothers $(49.17 \%)$ had attended secondary school. An overwhelming majority of children $(80.32 \%)$ came from rural areas. Nearly one quarter $(21.93 \%)$ children were aged between $12-35$ months and $12.24 \%$ children were less than six months of age. The highest percentage of children $(26.18 \%)$ lived in poorest households and the lowest percentage of children (14.96\%) lived in richest households in the category of wealth index quintile. $42.68 \%$ children had access to a flush toilet, whereas a majority (57.32\%) households had access to a pit toilet or hanging latrine. Around $21 \%$ of fathers had not undertaken any formaleducation, however, approximately $16 \%$ of fathers were found to have completed secondary or higher secondary education.

\section{Table 1 should be pasted here}

\section{Risk factors for child stunting}

Similar proportions of male children (26.46\%) and female children $(25.42 \%)$ were classified as stunted (Table 1 ). The prevalence rate of stunting was highest for those children whose parents had no education and whose family used a hanging toilet. Half of the children classified as stunted were aged between 24-35 months. The greatest proportion of children stunted, were from Sylhet division (34.24\%) and the lowest proportion from Khulna division (20.01\%).

In bivariate analysis, the following variables were significantly associated with stunting prevalence: age $(p<0.001)$, gender $(p<0.001)$, area $(p<0.001)$, division $(p<0.001)$, education of mother $(p<0.001)$, education of father $(p<0.001)$, wealth index quintile $(p<0.001)$, type of toilet facility $(p<0.001)$ and salt iodization test outcome $(\mathrm{p}<0.001)$.

Table 2 shows the results for binary logistic regression analysis on the risk factors associated with child stunting. Children's age was a significant predictor of stunting. Those aged twelve months to less than twentyfour months had significantly higher odds for stunting [OR: 2.16, 95\% Cl: 1.88-2.48], compared to children below six months of age. Children aged twenty-four to less than thirty-six months had almost three-fold odds on stunting [OR: 2.65, 95\% Cl: 2.30-3.05], compared to the children aged less than six months. Children living in Khulna division were significantly less likely to be stunted [OR: $0.71,95 \% \mathrm{Cl}: 0.62-0.81$ ], compared with the children who lived in Dhaka division. Children from Sylhet division had significantly higher odds in developing stunting compared with children from Dhaka division [OR: 1.26, 95\% Cl: 1.09-1.46]. Across categories of parental education, children whose mothers had completed secondary level education or higher were less likely to be stunted in comparison with the children whose mothers had no formal education [OR: $0.66,95 \% \mathrm{Cl}: 0.56-0.79$ ]. There were significantly lower odds of stunting for the children whose fathers had completed secondary education or higher [OR: $0.74,95 \% \mathrm{Cl}: 0.63-0.87$ ], compared to those children whose father had no formal education. Children from households with middle category in wealth index quintile were less likely to be stunted [OR: $0.69,95 \% \mathrm{Cl}: 0.62-0.77$ ] than the children.

\section{Table 2 should be pasted here}


from households with poorest category. Children of wealthiest families had $59 \%$ lower odds of stunting [OR: $0.49,95 \% \mathrm{Cl}: 0.41-0.58]$, compared to those from poorest families. Children from families which used hanging toilet had greater odds of stunting [OR: 1.21,95\% Cl: 1.03-1.41], compared with those from those families that used flush toilet.

Table 3 shows the effects of parental combined level of education on the risk of child stunting after adjustment for; household member, age, gender, area, division, wealth index, type of toilet facility, salt iodization test outcome and number of under five children. The results suggest that one parent with primary school and one with secondary school and above [OR: $0.73,95 \% \mathrm{Cl}: 0.63-0.84$ ] and both parents with secondary school and above [OR: $0.59,95 \% \mathrm{Cl}: 0.52-0.69$ ] had significantly lower likelihood on stunting among their children when compared with children of parents who both had no education.

\section{Risk factors for severe stunting}

Table 1 shows the proportion of children classified as severely stunted. The proportion of male children severely stunted $(8.18 \%)$ was similar to that of female children (7.73\%). A slightly higher percentage of rural children were severely stunted $(8.15 \%)$ compared with the urban children (7.23\%). The highest proportion of severely stunted children was found in the Sylhet division (10.93\%) and the lowest in the Khulna division (3.85\%). Approximately one-tenth of children, with their mothers had no education were severely stunted (10.93\%), and $\sim 6 \%$ were severely stunted if their mothers completed secondary education or higher. Similarly only 5.88 percent children were severely stunted whose fathers had completed secondary or higher education and more than one-tenth $(10.72 \%)$ children were severely stunted whose

\section{Table 3 should be pasted here}

father didn't go to school. Only $5.85 \%$ children from wealthiest families were severely stunted and $11.03 \%$ children from poorest families were severely stunted. The highest rate of severe stunting prevalence was found for children age between $24-35$ months $(10.37 \%)$ and the lowest rate for age less than six months $(6.21 \%)$.

In bivariate analysis, the following variables were significantly associated with the prevalence of severe stunting: age $(p<0.001)$, division $(p<0.001)$, education of mother $(p<0.001)$, education of father $(p<0.001)$, wealth index $(p<0.001)$, type of toilet facility $(p<0.001)$ and salt iodization test outcome $(p<0.001)$. Table 4 shows the results on the binary logistic regression analysis on the risk factors that associated with the risk for severe stunting among the children five years and below. Children aged twenty-four to less than thirty six months were almost two times more likely to be severely stunted [OR: $1.85,95 \% \mathrm{Cl}: 2.37-3.52]$, compared with the children below six months of age. There was $44 \%$ higher the risk of severe stunting for children who were aged thirty six to less than forty eight months [OR: $1.44,95 \% \mathrm{Cl}: 1.15-1.80]$, compared to those who were less than six month of age. Children with a mother with formal education either secondary incomplete [OR: $0.68,95 \% \mathrm{Cl}$ : 0.57-0.82] or secondary complete or higher [OR: $0.59,95 \% \mathrm{Cl}: 0.44-0.77$ ] were significantly less likely to be severely stunted, compared with the children whose mothers had not any formal education. Moreover, children whose fathers had education level secondary incomplete had $19 \%$ lower odds that they could be severely stunted. Children had $57 \%$ lower odds to be severely stunted if they lived in Khulna division [OR: $0.43,95 \%$ Cl:0.34-0.54], compared with the children who lived in Dhaka division. Across categories of wealth, those who were in the fourth category in wealth index quintile had $37 \%$ lower odds on severe stunting relative to children from poorest families. Children from wealthiest families had $44 \%$ lower odds of severe stunting than the children who lived in poorest families. 
The results from table 5 suggests that after adjustment for; household member, age, gender, area, division, wealth index, type of toilet facility, salt iodization test outcome and number of under five children in a household, any increase in the level of parental education is associated with lower odds of severe stunting among children below 5 years.

\section{Discussion}

This study examined the prevalence rate of stunting among a large sample of Bangladeshi children aged $<5$ years. Our data showed that national prevalence rate for child stunting is at $25.96 \%$. This prevalence is remarkably lower than the $41 \%$ observed in 2007[22], suggesting that child stunting in Bangladesh has declined over time.

A key finding was that our adjusted analysis showed that children living in Sylhet division had the highest risk for being stunted. This was somewhat surprising because a large proportion of Bangladeshi's total income is received by the people of Sylhet division. In addition, food security status in this region has been suggested to be relatively better than the other divisions of Bangladesh [22]. Furthermore, the rate of poverty is lower in Sylhet division compared with other divisions in Bangladesh [23]. Poor educational opportunities and access, adverse maternal health [64] might explain why children from Sylhet division had high odds of child stunting. Even though Sylhet is suggested to have better economic condition than any other region of the country, it is important to note that there are still inequalities in this region. For example, the Sylhet region is geographically heterogeneous with tea gardens, hills and haors. In those areas transport facilities are poor which hinders students to attend schools and hence there are few opportunities for educational attainment by children. Our findings suggest that future research is needed to determine the factors associated with the high prevalence rate of child stunting in the Sylhet region.

A further key finding of the present study was that wealth index was a significant protective factor against child stunting. This finding is consistent with other studies showing that household socioeconomic status was a significant predictor of child stunting [24-29]. A study conducted by Talukder, reported that Bangladeshi children living in the poorest household had $38 \%$ higher odds for malnourishment compared to the children from wealthiest family [30]. The lower odds for child stunting associated with higher wealth index might be explained by the fact that children from wealthier families have better access to health facilities, better environmental conditions such as potable water, sanitation and access to sufficient food. It might also be that parents from wealthiest families have a higher education and more responsible for the health of their children when compared with parents from the poorest households. Other studies have shown that low quality housing and no access to potable water were significantly associated with child stunting [31, 32]. According to UNICEF (1990), major determinants of nutritional condition for a child are access to sufficient food supplies, improved health facilities and access to safe potable water supplies that are determined by household economic status [30]. The key findings from the present study suggest that improvement in household wealth status can possibly have significant impact on the reduction of reduce the probability of child stunting.

Consistent with other studies, we showed that maternal education has significant impact in reducing the chance for a child to be stunted [33-35; 2, 25, 4]. The presence of an educated mother might lead to a better understanding of nutritional conditions for her children. Better child feeding practices, for instance, exclusive breast feeding during first six months of a newborn child and timely initiation of complementary foods for 
children have been identified to be significantly associated with lower risk of child stunting [36]. More educated mothers may earn more money and therefore they may have more opportunity to invest in the health of their children [37]. Moreover, educated mothers are more likely to make better use of health care for their children [38, $39]$, to make efficient use of family resources $[40,41]$ and more willing to utilise family planning [18].

A further outcome from the present study was that a child's age had a significant impact on child stunting. The chances of a child to being stunted increased with age and reached at peak at 24-35 months. The finding is supported by other studies $[41,44,45]$. A potential cause of this might be that as the age of a child increases, biological factors and socioeconomic factors become greater determinants of stunting. It has been reported that male children had the higher chance of being stunted compared with female children [46, 47]. However, our study failed to establish significant association by gender for increased odds of stunting or severe stunting.

Children from households where salt was found to be adequately iodized ( $\geq 15$ PPM in salt iodization test) had significantly lower odds on stunting, compared with the children from households where salt was found as not iodized (0 PPM). The role of iodized salt as an important protective factor against stunting was supported by other studies which also suggest iodized salt reduces the risk of stunting $[55,56]$. Research has shown that iodine is crucial for normal physical growth [54] and insufficient intake of iodine by children during infancy and childhood could cause impaired growth $[57,58]$.

There are some limitations in the study that should be acknowledged. First, the cross-sectional design limits the possibility of determining causal relationships. Moreover, many studies have shown a seasonal impact on the prevalence of stunting especially in the rural areas of developing countries $[59,60]$. Given our study design, we were not able to assess seasonal impact. A further limitation was that there was no information on childbirth weight, paternal height, maternal height and maternal age, all of which have been reported as significant predictor of child malnutrition (20,40-). Strengths of the study include the use of a large representative sample size with a standardized questionnaire. This allows for comparisons with future data collected as a part of the Bangladeshi Multiple Indicators Cluster Survey.

\section{Conclusion}

Among a large sample of Bangladeshi children aged < 5 years, $\sim 25.96 \%$ were classified as stunted. Key risk factors for child stunting included increased age, living in Sylhet division and more under five children in a household using a pit toilet or a hanging toilet. In contrast, protective factors against child stunting were higher level of parental education and living in higher wealth index. Importantly, the risk factors as well as protective factors were similar between stunting and severe stunting implying intervention targeting the reduction of child stunting could eventually reduce the prevalence of severe stunting among children below five years of age. Our study suggested that parental education is a major protective factor that plays a crucial role in reducing the risk for a child to be stunted or severely stunted, therefore, we recommend promotion of education both for men and women. Higher level of maternal education would improve child nutritional conditions through its role on influencing child feeding and childcare.

Promotion of paternal education would improve child nutritional condition primarily through a generation of higher income and living in better neighbourhoods that is living in areas where there are greater medical facilities and cleaner environment. Another crucial protective factor indicated by the study is that socioeconomic status 
measured by the wealth index quintile. As regional differences appeared as a significant predictor of child stunting and severe stunting, for instance children living in Sylhet division are in higher risk for being stunted and severely stunted, geographical targeting should be adopted by governments and stakeholders on reducing stunting prevalence.

To reduce stunting prevalence in Bangladesh, policies should be implemented that focus on the risk factors determined by the study. Interventions regarding parental education and reducing socio-economic inequality may have long lasting beneficial effects on child malnutrition.

\section{Abbreviations}

HAZ Height for Age Z Score

MDGs Millennium Development Goals

OR Odds Ratio

PPM Parts Per Million

SD Standard Deviation

SDGs Sustainable Development Goals

UNICEF United Nations International Children's Emergency Fund

VIF Variance Inflation Factor

WHO World Health Organization

\section{Declarations}

\section{Ethics approval and consent to participate}

Not applicable.

\section{Consent for publication}

Not applicable.

\section{Availability of data and materials}

The analysis was based on the Bangladesh Multiple Indicators Cluster Survey (MICS)- 2019 data, collected by Bangladesh Bureau of Statistics along with UNICEF who provided technical and financial support, data is available upon request at https://mics.unicef.org/surveys

\section{Competing interests}

The authors declare that they have no competing interests. 


\section{Funding}

No direct funding received for this paper.

\section{Authors' contributions}

TRC managed the dataset and analyze the data and wrote the script. SC conceptualized and synthesized the analysis, interpreted findings and assisted in writing and editing. MR assisted to interpret and outline the findings with writing. SW and JB assisted in writing and editing.

\section{Acknowledgements}

We would like to thank Professor Lindsay Brown for providing us a critical review and comments on the paper.

\section{References}

1. Chen LC, Chowdhury AK, Huffman SL. Anthropometric assessment of energy-protein malnutrition and subsequent risk of mortality among preschool aged children. The American journal of clinical nutrition. 1980; 33(8):1836-45.

2. Rahman A. Significant risk factors for childhood malnutrition: Evidence from an Asian developing country. Science Journal of Public Health. 2016; doi: 10.11648/j.sjph.s.2016040101.14

3. Shetty P. Malnutrition and undernutrition. Medicine. 2003; 31(4):18-22.

4. Onis M, Dewey KG, Borghi E, Onyango AW, Blössner M, Daelmans B, et al. The World Health Organization's global target for reducing childhood stunting by 2025: rationale and proposed actions. Maternal \& child nutrition. 2013; doi: 10.1111/mcn.12075.

5. International Food Policy Research Institute, Global Nutrition Report 2016: From Promise to Impact: Ending Malnutrition by 2030, 2016.

6. Black RE, Allen LH, Bhutta ZA, Caulfield LE, De Onis M, Ezzati M, et al. Maternal and child undernutrition: global and regional exposures and health consequences. The lancet. 2008; 371:243-60.

7. Victora CG, Adair L, Fall C, Hallal PC, Martorell R, Richter L, et al. Maternal and child undernutrition: consequences for adult health and human capital. The lancet. 2008; 371(9609):340-57.

8. Black RE, Victora CG, Walker SP, Bhutta ZA, Christian P, De Onis M, et al. Maternal and child undernutrition and overweight in low-income and middle-income countries. The Lancet. 2013; 382: 427-5.

9. Victora CG, Fuchs SC, Flores JA, Fonseca W, Kirkwood B. Risk factors for pneumonia among children in a Brazilian metropolitan area. Pediatrics. 1994; 93(6):977-85.

10. Pelletier DL. Potentiating effects of malnutrition on child mortality: epidemiologic evidence and policy implications. Food Nutr Bull. 1995; 16:206-13.

11. McCarthy M. Stunted children are at high risk of later obesity. The Lancet. 1997; 349:34.

12. Jesmin A, Yamamoto SS, Malik AA, Haque MA. Prevalence and determinants of chronic malnutrition among preschool children: a cross-sectional study in Dhaka City, Bangladesh. Journal of Health, Population and Nutrition. 2011; 29(5):494-9.

13. Chang SM, Walker SP, Grantham-McGregor S, Powell CA. Early childhood stunting and later behavior and school achievement. Journal of Child Psychology and Psychiatry. 2002; doi: 10.1111/1469-7610.00088. 
14. Martorell R, Delgado HL, Delgado H, Valverde V, Klein RE. Maternal stature, fertility and infant mortality. Human Biology. 1981; 53(3):303-12.

15. Behrman J, Hoddinott J. An Evaluation of the Impact of PROGRESA on Preschool Child Height. International Food Policy Research Institute. Food Consumption and Nutrition Division. Discussion Paper; 2001

16. Grantham-McGregor S, Cheung YB, Cueto S, Glewwe P, Richter L, Strupp B, et al. Developmental potential in the first 5 years for children in developing countries. The lancet. 2007; 369(9555):60-70.

17. Frongillo EA, de Onis M, Hanson KM. Socioeconomic and demographic factors are associated with worldwide patterns of stunting and wasting of children. The Journal of nutrition. 1997; 127(12):2302-9.

18. Senbanjo IO, Oshikoya KA, Odusanya OO, Njokanma OF. Prevalence of and risk factors for stunting among school children and adolescents in Abeokuta, southwest Nigeria. Journal of Health, Population and Nutrition. 2011; 29(4):364-70.

19. Sharma AK, Baig VN, Yadav AK, Bharadwaj AK, Singh R. Prevalence and Risk Factors for Stunting Among Tribal Under-Five Children At South-West, Rajasthan, India. National Journal of Community Medicine. 2016; 7(6):461-7.

20. Ricci JA, Becker S. Risk factors for wasting and stunting among children in Metro Cebu, Philippines. The American journal of clinical nutrition. 1996; 63(6):966-75.

21. Bangladesh Bureau of Statistics (BBS) and UNICEF Bangladesh. 2019. Progotir Pathey, Bangladesh Multiple Indicator Cluster Survey 2019, Survey Findings Report. Dhaka, Bangladesh: Bangladesh Bureau of Statistics (BBS). Retrieved from

https://www.unicef.org/bangladesh/media/3281/file/Bangladesh\%202019\%20MICS\%20Report_English.pdf

22. Mohsena M, Goto R, Mascie-Taylor CG. Regional variation in maternal and childhood undernutrition in Bangladesh: evidence from demographic and health surveys. Who South-East Asia Journal of Public Health. 2015; 4(2): 139-149.

23. Titumir RAM, Rahman KMM. Poverty and inequality in Bangladesh. 2011. Retrieved from http://www.unnayan.org/reports/Poverty_and_Inequality_in_Bangladesh.pdf

24. Kanjilal B, Mazumdar PG, Mukherjee M, Rahman MH. Nutritional status of children in India: household socio-economic condition as the contextual determinant. International Journal for equity in Health. 2010; doi: 10.1186/1475-9276-9-19.

25. SM MK. Socio-economic determinants of severe and moderate stunting among under-five children of rural Bangladesh. Mal J Nur. 2011; 17(1): 105-118.

26. Hong R, Mishra V. Effect of wealth inequality on chronic under-nutrition in Cambodian children. Journal of Health, Population and Nutrition. 2006; 24:89-99.

27. Agee MD. Reducing child malnutrition in Nigeria: combined effects of income growth and provision of information about mother's access to health care services. Social science \& medicine. 2010; 71: $1973-80$.

28. Van de Poel E, Hosseinpoor AR, Speybroeck N, Van Ourti T, Vega J. Socioeconomic inequality in malnutrition in developing countries. Bulletin of the World Health Organization. 2008; 86(4):282-91.

29. Delpeuch F, Traissac P, Martin-Prével Y, Massamba JP, Maire B. Economic crisis and malnutrition: socioeconomic determinants of anthropometric status of preschool children and their mothers in an African urban area. Public health nutrition. 2000; 3(01):39-47. 
30. Talukder B. Regional Differences of Child Under-Nutrition in Bangladesh. Finnish Yearbook of Population Research. 2013; 48:189-201.

31. Fernandez ID, Himes JH, Onis MD. Prevalence of nutritional wasting in populations: building explanatory models using secondary data. Bulletin of the World Health Organization. 2002; 80(4):282-91.

32. El-Sayed N, Mohamed AG, Nofal L, Mahfouz A, Zeid HA. Malnutrition among pre-school children in Alexandria, Egypt. Journal of Health, Population and Nutrition. 2001; 19(4):275-80.

33. Rahman A, Chowdhury S. Determinants of chronic malnutrition among preschool children in Bangladesh. Journal of biosocial science. 2007; 39(2):161-173

34. Megabiaw B, Rahman A. Prevalence and determinants of chronic malnutrition among under-5 children in Ethiopia. International Journal of Child Health and Nutrition. 2013; 2(3):230-6.

35. Abuya BA, Onsomu EO, Moore D. Influence of maternal education on child immunization and stunting in Kenya. Maternal and Child Health Journal. 2011; doi: 10.1007/s10995-010-0670-z.

36. Ruel MT, Menon P. Child feeding practices are associated with child nutritional status in Latin America: innovative uses of the demographic and health surveys. The Journal of nutrition. 2002; 132(6):1180-7.

37. Maïga EW. The Impact of Mother's Education on Child Health and Nutrition in Developing Countries: Evidence from a Natural Experiment in Burkina Faso. African Center for Economic Transformation. Accra, Ghana. 2011.

38. Caputo A, Foraita R, Klasen S, Pigeot I. Undernutrition in Benin-an analysis based on graphical models. Social science \& medicine. 2003; 56:1677-91.

39. Aerts D, Drachler ML, Giugliani ERJ. Determinants of growth retardation in Southern Brazil. Cadernos de Saúde Pública. 2004; 20: 1182-1190.

40. Semba RD, de Pee S, Sun K, Sari M, Akhter N, Bloem MW. Effect of parental formal education on risk of child stunting in Indonesia and Bangladesh: a cross-sectional study. The Lancet. 2008; 371(9609):322-8.

41. Agho KE, Inder KJ, Bowe SJ, Jacobs J, Dibley MJ. Prevalence and risk factors for stunting and severe stunting among under-fives in North Maluku province of Indonesia. BMC pediatrics. 2009; doi: 10.1186/1471-2431-9-64

42. Tharakan CT, Suchindran CM. Determinants of child malnutrition-an intervention model for Botswana. Nutrition Research. 1999;19(6):843-60.

43. Shinsugi C, Matsumura M, Karama M, Tanaka J, Changoma M, Kaneko S. Factors associated with stunting among children according to the level of food insecurity in the household: a cross-sectional study in a rural community of South-eastern Kenya. BMC public health. 2015; 10.1186/s12889-015-1802-6.

44. Pongou R, Ezzati M, Salomon JA. Household and community socioeconomic and environmental determinants of child nutritional status in Cameroon. BMC public health. 2006; doi: 10.1186/1471-2458-698.

45. Kumar D, Goel NK, Mittal PC, Misra P. Influence of infant-feeding practices on nutritional status of under-five children. Indian Journal of pediatrics. 2006; doi: 10.1007/BF02758565.

46. Hoffman DJ, Sawaya AL, Coward WA, Wright A, Martins PA, de Nascimento C, et al. Energy expenditure of stunted and non stunted boys and girls living in the shantytowns of Sao Paulo, Brazil. The American journal of clinical nutrition. 2000; 72(4):1025-31. 
47. Prista A, Maia JA, Damasceno A, Beunen G. Anthropometric indicators of nutritional status: implications for fitness, activity, and health in school-age children and adolescents from Maputo, Mozambique. The American journal of clinical nutrition. 2003; 77(4):952-9.

48. Aguillon DB, Caedo MM, Arnold JC, Engel RW. The relationship of family characteristics to the nutritional status of pre-school children. Food and Nutrition Bulletin. 1982;4(4):5-12.

49. Wray JD, Aguirre A. Protein-calorie malnutrition in Candelaria, Colombia. I. Prevalence: social and demographic causal factors. Journal of Tropical Pediatrics. 1969;15(3):76-98.

50. Waterlow JC, Buzina R, Keller W, Lane JM, Nichaman MZ, Tanner JM. The presentation and use of height and weight data for comparing the nutritional status of groups of children under the age of 10 years. Bulletin of the World Health Organization. 1977;55(4):489.

51. WHO Multicentre Growth Reference Study Group. WHO Child Growth Standards: Methods and development: Length/height-for-age, weight-for-age, weight-for-length, weight-for-height and body mass index-for-age. Geneva: World Health Organization. 2006.

52. Aguayo VM, Badgaiyan N, Paintal K. Determinants of child stunting in the Royal Kingdom of Bhutan: an indepth analysis of nationally representative data. Maternal \& child nutrition. 2015 Jul 1;11(3):333-45.

53. Sarma H, Khan JR, Asaduzzaman M, Uddin F, Tarannum S, Hasan MM, Rahman AS, Ahmed T. Factors Influencing the Prevalence of Stunting Among Children Aged Below Five Years in Bangladesh. Food and nutrition bulletin. 2017 Sep;38(3):291-301.

54. Farebrother J, Naude CE, Nicol L, Sang Z, Yang Z, Andersson M, Jooste PL, Zimmermann MB. Systematic review of the effects of iodised salt and iodine supplements on prenatal and postnatal growth: study protocol. BMJ open. 2015 Apr 1;5(4):e007238.

55. Fenske N, Burns J, Hothorn T, Rehfuess EA. Understanding child stunting in India: a comprehensive analysis of socio-economic, nutritional and environmental determinants using additive quantile regression. PloS one. 2013 Nov 4;8(11):e78692.

56. Das S, Hossain MZ, Islam MA. Predictors of child chronic malnutrition in Bangladesh. Proceedings of Pakistan Academy of Sciences. 2008; 45(3); 137-55

57. Zimmermann MB. The effects of iodine deficiency in pregnancy and infancy. Paediatric and perinatal epidemiology. 2012 Jul 1;26(s1):108-17.

58. World Health Organization. Assessment of iodine deficiency disorders and monitoring their elimination: a guide for programme managers. World Health Organization 2007.

59. Egata G, Berhane Y, Worku A. Seasonal variation in the prevalence of acute undernutrition among children under five years of age in east rural Ethiopia: a longitudinal study. BMC Public Health. 2013;13:864. doi:10.1186/1471-2458-13-864.

60. Burza S, Mahajan R, Marino E, et al. Seasonal effect and long-term nutritional status following exit from a Community-Based Management of Severe Acute Malnutrition program in Bihar, India. European Journal of Clinical Nutrition. 2016;70(4):437-444. doi:10.1038/ejcn.2015.140.

61. Kismul H, Acharya P, Mapatano MA, Hatløy A. Determinants of childhood stunting in the Democratic Republic of Congo: further analysis of Demographic and Health Survey 2013-14. BMC public health. 2018 Dec;18(1):74. 
62. Fikadu T, Assegid S, Dube L. Factors associated with stunting among children of age 24 to 59 months in Meskan district, Gurage Zone, South Ethiopia: a case-control study. BMC Public Health. 2014 Dec;14(1):800.

63. Cohen, J., Cohen, P., West, S. G., \& Aiken, L. S. Applied multiple regression/correlation analysis for the behavioral sciences. Routledge. 2013.

64. Chowdhury, T.R., Chakrabarty, S., Rakib, M. et al. Global Health (2018) 14: 54. https://doi.org/10.1186/s12992-018-0372-7

65. Prendergast AJ, Humphrey JH. The stunting syndrome in developing countries. Paediatrics and international child health. 2014 Nov 1;34(4):250-65.

\section{Tables}

Table 1 The bivariate distribution of stunting and severe stunting with sample characteristics 


\begin{tabular}{|c|c|c|c|c|c|}
\hline \multirow[t]{2}{*}{ Characteristics } & \multirow{2}{*}{$\begin{array}{l}\text { Total Sample } \\
(\mathrm{n}=17490)\end{array}$} & \multicolumn{2}{|l|}{ Stunted } & \multicolumn{2}{|c|}{ Severely Stunted } \\
\hline & & $\begin{array}{l}\text { Proportions } \\
\text { (\%) }\end{array}$ & P-value & $\begin{array}{l}\text { Proportions } \\
\text { (\%) }\end{array}$ & P-value \\
\hline Household Members & & & 0.163 & & 0.069 \\
\hline$<=3$ & 14.16 & 26.94 & & 7.75 & \\
\hline $4-6$ & 68.64 & 25.54 & & 7.75 & \\
\hline$>=7$ & 17.20 & 26.86 & & 9.01 & \\
\hline Age (Months) & & & $<0.001$ & & $<0.001$ \\
\hline 0 to $<6$ & 12.24 & 16.30 & & 6.21 & \\
\hline 6 to $<12$ & 10.87 & 18.67 & & 6.31 & \\
\hline 12 to $<24$ & 21.93 & 28.47 & & 9.05 & \\
\hline 24 to $<36$ & 20.06 & 32.29 & & 10.37 & \\
\hline 36 to $<48$ & 18.78 & 29.32 & & 8.16 & \\
\hline 48 to $<60$ & 16.12 & 23.02 & & 5.75 & \\
\hline Gender & & & $<0.001$ & & 0.271 \\
\hline Male & 52.53 & 26.46 & & 8.18 & \\
\hline Female & 47.47 & 25.42 & & 7.73 & \\
\hline Area & & & $<0.001$ & & 0.071 \\
\hline Urban & 19.68 & 22.75 & & 7.23 & \\
\hline Rural & 80.32 & 26.75 & & 8.15 & \\
\hline Division & & & $<0.001$ & & $<0.001$ \\
\hline Barishal & 9.35 & 26.67 & & 8.62 & \\
\hline Chattogram & 18.20 & 25.45 & & 7.98 & \\
\hline Dhaka & 18.93 & 26.00 & & 8.76 & \\
\hline Khulna & 14.86 & 20.01 & & 3.85 & \\
\hline Mymenshing & 6.11 & 30.99 & & 9.08 & \\
\hline Rajshahi & 11.64 & 25.06 & & 6.49 & \\
\hline Rangpur & 13.39 & 26.56 & & 10.08 & \\
\hline Sylhet & 7.53 & 34.24 & & 10.93 & \\
\hline Education of Mother & & & $<0.001$ & & $<0.001$ \\
\hline
\end{tabular}




\begin{tabular}{|c|c|c|c|c|c|}
\hline \multirow[t]{2}{*}{ Characteristics } & \multirow{2}{*}{$\begin{array}{l}\begin{array}{l}\text { Total Sample } \\
(\mathrm{n}=17490)\end{array} \\
\begin{array}{l}\text { Proportions } \\
(\%)\end{array}\end{array}$} & \multicolumn{2}{|l|}{ Stunted } & \multicolumn{2}{|c|}{ Severely Stunted } \\
\hline & & $\begin{array}{l}\text { Proportions } \\
\text { (\%) }\end{array}$ & P-value & $\begin{array}{l}\text { Proportions } \\
\text { (\%) }\end{array}$ & P-value \\
\hline Pre-primary or none & 10.89 & 36.82 & & 12.50 & \\
\hline Primary & 24.87 & 30.97 & & 10.05 & \\
\hline Secondary & 49.17 & 23.64 & & 6.71 & \\
\hline Higher secondary+ & 15.08 & 17.44 & & 5.38 & \\
\hline Education of Father & & & $<0.001$ & & $<0.001$ \\
\hline None (0) & 20.80 & 33.40 & & 10.72 & \\
\hline Primary $(1$ to $<6)$ & 31.98 & 28.66 & & 8.87 & \\
\hline Secondary incomplete $(6$ to $<10)$ & 31.18 & 22.81 & & 6.29 & \\
\hline Secondary complete or higher $(\geq 10)$ & 16.04 & 17.08 & & 5.88 & \\
\hline Wealth Index quintile & & & $<0.001$ & & $<0.001$ \\
\hline Poorest & 26.18 & 34 & & 11.03 & \\
\hline Second & 22.37 & 28.35 & & 8.51 & \\
\hline Middle & 18.87 & 24 & & 6.55 & \\
\hline Fourth & 17.62 & 21.12 & & 6.07 & \\
\hline Richest & 14.96 & 17.04 & & 5.85 & \\
\hline Type of toilet facility & & & $<0.001$ & & $<0.001$ \\
\hline Flush latrin & 42.68 & 22 & & 6.82 & \\
\hline Pit and hanging latrin & 57.32 & 29.14 & & 8.83 & \\
\hline Salt lodization test outcome & & & $<0.001$ & & $<0.001$ \\
\hline 0 PPM (not iodized) & 25.73 & 28 & & 9.04 & \\
\hline More than 0 PPM and less than 15 PPM & 19.01 & 28.19 & & 8.90 & \\
\hline 15 PPM or more & 54.75 & 24 & & 7.13 & \\
\hline No salt in the household & 0.51 & 35 & & 8.99 & \\
\hline \multicolumn{6}{|l|}{ Stunting condition } \\
\hline Stunted (HAZ score <-2 SD) & 25.96 & & & & \\
\hline Severely stunted $(H A Z<-3 S D)$ & 7.97 & & & & \\
\hline
\end{tabular}


Table 2 Risk factors for stunting (HAZ scores < -2SD) among children aged less than five years 


\begin{tabular}{|c|c|c|c|}
\hline Factors & & OR & $95 \% \mathrm{Cl}$ \\
\hline \multirow[t]{3}{*}{ Household member } & $\leq 3$ & ref & \\
\hline & $4-6$ & 0.90 & {$[0.81-1.00]^{\star \star}$} \\
\hline & $\geq 7$ & 0.98 & [0.86 - 1.11] \\
\hline \multirow[t]{6}{*}{ Age (Months) } & 0 to $<6$ & ref & \\
\hline & 6 to $<12$ & 1.23 & {$[1.04-1.45]^{\star \star}$} \\
\hline & 12 to $<24$ & 2.16 & {$[1.88-2.48]^{\star \star \star}$} \\
\hline & 24 to $<36$ & 2.65 & {$[2.30-3.05]^{\star \star \star}$} \\
\hline & 36 to $<48$ & 2.33 & {$[2.02-2.69]^{\star \star \star}$} \\
\hline & 48 to $<60$ & 1.67 & {$[1.44-1.95]^{\star \star \star}$} \\
\hline \multirow[t]{2}{*}{ Gender } & Male & ref & \\
\hline & Female & 0.94 & {$[0.88-1.01]$} \\
\hline \multirow[t]{2}{*}{ Area } & Urban & ref & \\
\hline & Rural & 0.90 & {$[0.81-1.00]^{\star \star}$} \\
\hline \multirow[t]{8}{*}{ Division } & Dhaka & ref & \\
\hline & Barishal & 0.87 & {$[0.76-1.01]^{\star}$} \\
\hline & Chattogram & 0.87 & {$[0.77-0.97]^{\star \star}$} \\
\hline & Khulna & 0.71 & {$[0.62-0.81]^{\star \star \star}$} \\
\hline & Mymenshing & 1.06 & [0.91 - 1.25] \\
\hline & Rajshahi & 0.89 & {$[0.78-1.01]^{\star}$} \\
\hline & Rangpur & 0.90 & [0.79 - 1.02] \\
\hline & Sylhet & 1.26 & {$[1.09-1.46]^{\star \star \star}$} \\
\hline \multirow[t]{4}{*}{ Education of mother (schooling years) } & None (0) & ref & \\
\hline & Primary $(1$ to $<6)$ & 0.87 & {$[0.77-0.99]^{\star \star}$} \\
\hline & Secondary incomplete $(6$ to $<10)$ & 0.74 & {$[0.65-0.83]^{\star \star \star}$} \\
\hline & Secondary complete or higher $(\geq 10)$ & 0.66 & {$[0.56-0.79]^{\star \star \star}$} \\
\hline \multirow[t]{4}{*}{ Education of father (schooling years) } & None $(0)$ & ref & \\
\hline & Primary $(1$ to $<6)$ & 0.95 & {$[0.86-1.04]$} \\
\hline & Secondary incomplete $(6$ to $<10)$ & 0.83 & {$[0.75-0.93]^{\star \star \star}$} \\
\hline & Secondary complete or higher $(\geq 10)$ & 0.74 & {$[0.63-0.87]^{\star \star \star}$} \\
\hline Wealth index quintile & Poorest & ref & \\
\hline
\end{tabular}




\begin{tabular}{|llll|}
\hline Factors & & OR & $95 \% \mathrm{Cl}$ \\
\hline & Second & 0.83 & {$[0.75-0.91]^{\star \star \star}$} \\
\hline Middle & 0.69 & {$[0.62-0.77]^{\star \star \star}$} \\
\hline Fourth & 0.63 & {$[0.55-0.72]^{\star \star \star}$} \\
\hline Roilet facility & Richest & 0.49 & {$[0.41-0.58]^{\star \star \star}$} \\
\hline Salt idolization test & Flush latrine & ref & \\
\hline & Pitn and hanging latrine & 0.99 & {$[0.91-1.09]$} \\
\hline & 0 PPM (not iodized) & ref & \\
\hline & More than 0 PPM and less than 15 PPM & 1.01 & {$[0.91-1.12]$} \\
\hline Number of under five children & 15 PPM or more & 0.98 & {$[0.90-1.07]$} \\
\hline
\end{tabular}

$* \star * p<0.001, * * p<0.01, * p<0.05$

Table 3 Effects of parental combined level of education on the risk of stunting

\begin{tabular}{|lll|}
\hline Level of Education & OR & $\mathbf{9 5 \%} \mathbf{C l}$ \\
\hline Level 1 & Ref. & \\
\hline Level 2 & 0.94 & {$[0.81-1.10]$} \\
\hline Level 3 & 0.78 & {$[0.66-0.93]^{\star \star \star}$} \\
\hline Level 4 & 0.84 & {$[0.72-0.97]^{\star \star}$} \\
\hline Level 5 & 0.73 & {$[0.63-0.84]^{\star \star \star}$} \\
\hline Level 6 & 0.59 & {$[0.52-0.69]^{\star \star \star}$} \\
\hline
\end{tabular}

$\star * \star p<0.001, * * p<0.01, * p<0.05$

Level $1=$ both parents no education; Level $2=$ one with no education, one with primary school; Level $3=$ one with no education, one with secondary school and above; Level $4=$ both with primary school; Level $5=$ one with primary school, one with secondary school and above; and Level $6=$ both with secondary school and above [40]

Table 4 Risk factors for severe stunting (HAZ scores < -3SD) among children aged less than five years 


\begin{tabular}{|c|c|c|c|}
\hline Factors & & OR & $95 \% \mathrm{Cl}$ \\
\hline \multirow[t]{3}{*}{ Household member } & $\leq 3$ & ref & \\
\hline & $4-6$ & 0.95 & {$[0.80-1.12]$} \\
\hline & $\geq 7$ & 1.09 & [0.89 - 1.34] \\
\hline \multirow[t]{6}{*}{ Age (Months) } & 0 to $<6$ & ref & \\
\hline & 6 to $<12$ & 1.06 & [0.82 - 1.37] \\
\hline & 12 to $<24$ & 1.56 & {$[1.26-1.93]^{\star \star \star}$} \\
\hline & 24 to $<36$ & 1.85 & {$[1.50-2.29]^{\star \star \star}$} \\
\hline & 36 to $<48$ & 1.44 & {$[1.15-1.80]^{\star \star \star}$} \\
\hline & 48 to $<60$ & 0.99 & [0.77 - 1.26] \\
\hline \multirow[t]{2}{*}{ Gender } & Male & ref & \\
\hline & Female & 0.94 & [0.84 - 1.05] \\
\hline \multirow[t]{2}{*}{ Area } & Urban & ref & \\
\hline & Rural & 0.89 & {$[0.76-1.05]$} \\
\hline \multirow[t]{8}{*}{ Division } & Dhaka & ref & \\
\hline & Barishal & 0.88 & [0.71 - 1.10] \\
\hline & Chattogram & 0.82 & {$[0.69-0.99]^{\star \star}$} \\
\hline & Khulna & 0.43 & {$[0.34-0.54]^{\star \star \star}$} \\
\hline & Mymenshing & 0.88 & [0.69 - 1.12] \\
\hline & Rajshahi & 0.70 & {$[0.56-0.87]^{\star \star \star}$} \\
\hline & Rangpur & 1.06 & [0.88 - 1.28] \\
\hline & Sylhet & 1.08 & [0.87 - 1.34] \\
\hline \multirow[t]{4}{*}{ Education of mother (schooling years) } & None $(0)$ & ref & \\
\hline & Primary $(1$ to $<6)$ & 0.88 & {$[0.74-1.06]$} \\
\hline & Secondary incomplete $(6$ to $<10)$ & 0.68 & {$[0.57-0.82]^{\star \star \star}$} \\
\hline & Secondary complete or higher $(\geq 10)$ & 0.59 & {$[0.44-0.77]^{\star \star \star}$} \\
\hline \multirow[t]{4}{*}{ Education of father (schooling years) } & None $(0)$ & ref & \\
\hline & Primary $(1$ to $<6)$ & 0.97 & {$[0.83-1.13]$} \\
\hline & Secondary incomplete $(6$ to $<10)$ & 0.81 & {$[0.68-0.97]^{\star \star}$} \\
\hline & Secondary complete or higher $(\geq 10)$ & 0.96 & {$[0.75-1.24]$} \\
\hline Wealth index quintile & Poorest & ref & \\
\hline
\end{tabular}




\begin{tabular}{|llll|}
\hline Factors & & OR & $95 \% \mathrm{Cl}$ \\
\hline & Second & 0.83 & {$[0.71-0.97]^{\star \star}$} \\
\hline Middle & 0.67 & {$[0.56-0.81]^{\star \star \star}$} \\
\hline Fourth & 0.63 & {$[0.51-0.78]^{\star \star \star}$} \\
\hline Roilet facility & Richest & 0.56 & {$[0.43-0.74]^{\star \star \star}$} \\
\hline Salt idolization test & Flush latrine & ref & \\
\hline & Pitn and hanging latrine & 0.87 & {$[0.75-1.00]^{\star}$} \\
\hline & 0 PPM (not iodized) & ref & \\
\hline & More than 0 PPM and less than 15 PPM & 0.97 & {$[0.82-1.14]$} \\
\hline Number of under five children & 15 PPM or more & 0.89 & {$[0.77-1.02]$} \\
\hline
\end{tabular}

$* \star * p<0.001, * * p<0.01, * p<0.05$

Table 5 Effects of parental combined level of education on the risk of severe stunting

\begin{tabular}{|lll|}
\hline Level of Education & OR & $\mathbf{9 5 \% ~ C l}$ \\
\hline Level 1 & Ref. & \\
\hline Level 2 & 1.14 & {$[0.91-1.43]$} \\
\hline Level 3 & 0.89 & {$[0.69-1.16]^{\star \star \star}$} \\
\hline Level 4 & 0.93 & {$[0.74-1.17]^{\star \star}$} \\
\hline Level 5 & 0.74 & {$[0.60-0.92]^{\star \star \star}$} \\
\hline Level 6 & 0.63 & {$[0.50-0.78]^{\star \star \star}$} \\
\hline
\end{tabular}

$\star \star \star * p 0.001, * \star p<0.01, * p<0.05$

Level $1=$ both parents no education; Level $2=$ one with no education, one with primary school; Level $3=$ one with no education, one with secondary school and above; Level $4=$ both with primary school; Level $5=$ one with primary school, one with secondary school and above; and Level $6=$ both with secondary school and above [40] 